\title{
The first record of Trichocera (Saltrichocera) annulata (Diptera: Trichoceridae) in Romania, with additional data on Trichocera (Saltrichocera) maculipennis
}

\author{
Alexandru-Mihai Pintilioaie ${ }^{1}$, Levente-Péter Kolcsár ${ }^{2}$ \\ 1 Research Group in Invertebrate Diversity and Phylogenetics, Faculty of Biology, "Alexandru Ioan \\ Cuza" University of Iași, Romania \\ 2 Center for Marine Environmental Studies (CMES), Ehime University, Matsuyama, Ehime 790-8577, \\ Japan \\ Corresponding author: Alexandru-Mihai Pintilioaie (alexandrupintilioaie@gmail.com) \\ Received 8 January 2020 | Accepted 13 February 2020 | Published 30 June 2020 \\ Citation: Pintilioaie A-M, Kolcsár L-P (2020) The first record of Trichocera (Saltrichocera) annulata (Diptera: \\ Trichoceridae) in Romania, with additional data on Trichocera (Saltrichocera) maculipennis. Travaux du Muséum \\ National d'Histoire Naturelle "Grigore Antipa" 63(1): 83-86. https://doi.org/10.3897/travaux.63.e49965
}

\begin{abstract}
The Romanian Trichoceridae fauna is poorly known. Trichocera (Saltrichocera) annulata Meigen, 1818 and Trichocera (Saltrichocera) maculipennis Meigen, 1818 are amongst the most widespread species in Europe, but the former species was not recorded from Romania so far and the later has only 120 years old records. Herein we report T. (S.) annulata from Romania for the first time and bring new records for T. (S.) maculipennis. A total of 18 Trichocera species are known from Romania at the moment.
\end{abstract}

\section{Keywords}

Distribution, faunistic note, Tipulomorpha, winter gnats

The Trichoceridae family (also known as winter gnats or winter crane flies) comprises Tipulomorpha Diptera which are usually linked to cold temperatures, most of them being active even in the middle of winter. The representatives of Trichoceridae family bear a set of features that are not found in other Tipulomorpha: the presence of ocelli, the vein A2 very short, in most of the cases abruptly bent towards the wing margin and the ovipositor curved downwards (Freeman 1950). A significant number of species can be found in autumn, winter and spring, sometimes large 
numbers of males (consisting of one species) can be seen swarming in the afternoon, waiting for the females to join them for mating. Some species occur in basements, caves, mines and other cold and darkened places (Freeman 1950, Ujvárosi and Krzemińska 2002). The larvae can be found in decomposed vegetable matter (Freeman 1950).

From Europe, 2 genera were reported: Cladoneura Scudder, 1894 (= Diazosma Bergroth, 1913) and Trichocera Meigen, 1803 (Kolcsár et al. 2018). The widespread genus Trichocera comprises around 110 species (from a total of about 160 Trichoceridae species), distributed mainly in the Holarctic region (Petrašiūnas and Kvifte 2016). In Romania, this Diptera family was studied by Ujvárosi and Krzemińska (2002), who recorded 13 species of Trichoceridae new to Romania. Furthermore, Trichocera (Metatrichocera) ticina Starý \& Podènas, 1995, a rare species, was recently reported by Kolcsár et al. (2018).

Trichocera (Saltrichocera) annulata Meigen, 1818 is probably the most widespread winter gnat species in the world (Dahl and Alexander 1976, Krzemińska and Brunhes 1991, Krzemińska 1999, Petrašiūnas and Visarcuk 2007). It is characterized by a distinctly banded abdomen and unspotted wings, with the $\mathrm{d}$ cell broad, pentagonal (Freeman 1950, Krzemińska 1999). Trichocera (Saltrichocera) annulata shows an unusually high tolerance to warmer temperatures, having a wide distribution in Africa (Ethiopia, Algeria), Asia Minor and the Mediterranean region as well (Dahl and Alexander 1976, Petrašiūnas and Kvifte 2016). So far, it was recorded from North-America, Asia, Africa, most of the European countries (Dahl and Alexander 1976, Krzemińska and Brunhes 1991, Krzemińska 1999), but not from Romania, until now. The species was introduced to Australia (Alexander 1926) and New Zealand (Edwards 1928).

We examined 3 specimens from Romania, as follows: $1 \overbrace{}^{\lambda}$ România: Constanța county: Agigea (near): The Natural Reserve "Marine sand dunes of Agigea", $1-8.03 .2019,44.086562^{\circ} \mathrm{N} / 28.641887^{\circ} \mathrm{E}$, YPT (yellow pan traps), leg. Pintilioaie Alexandru; $2 \hat{\jmath}$ România: Harghita county: Ditrău, 26.12.2017, $46.807155^{\circ} \mathrm{N} / 25.504679^{\circ} \mathrm{E}$, leg. Kolcsár L.-P. Later specimens were collected by hand from the wall of a cellar together with Trichocera (Saltrichocera) maculipennis Meigen, 1818

T. (S.) maculipennis shows similar distribution pattern as T. (S.) annulata (Dahl and Alexander 1976, Potocka and Krzemińska 2018). The species is characterized by spotted wings, with uniform or banded abdomen (Volonterio et al. 2013, Petrašiūnas and Podenas 2017). It also tolerates warmer temperatures and occurs from Arctic to the Mediterranean region, from Greenland to Japan and was also introduced to some Southern Hemisphere Islands (Dahl and Alexander 1976, Volonterio et al. 2013, Driauach et al. 2015, Petrašiūnas and Podenas 2017, Potocka and Krzemińska 2018). The only known record from Romania is from Tășnad (Tasnád), reported 120 years ago by Thalhammer (1900).

Here we report additional records: 12 specimens from Romania, as follows: $5 \AA$ and $3 q$ România: Harghita county: Ditrău, 26.12.2017, $46.807155^{\circ} \mathrm{N} / 25.504679^{\circ} \mathrm{E}$, 
leg. Kolcsár L.-P.; 40̂, same location, 22.12.2017, leg. Kolcsár L.-P. Specimens were collected by hand from the wall of a cellar together with $T$. (S.) annulata.

All specimens are stored in $98 \%$ alcohol and deposited in the private collection of the second author.

At the moment, the data on Romanian Trichoceridae is scarce and contains records of 18 species. Increasing the sampling effort by using proper collecting techniques (sweeping the vegetation with an entomological net, using malaise traps and light traps) will certainly reveal new locations and probably new species of Trichoceridae for Romania.

\section{Acknowledgments}

We are thankful to the staff from Marine Biological Station "Prof. Dr. Ioan Borcea" Agigea of "Alexandru Ioan Cuza" University, Iași, for accommodation facilities and their help during data collecting there.

\section{References}

Alexander CP (1926) The Trichoceridae of Australia (Diptera). Proceedings of the Linnean Society of New South Wales 60: 298-304.

Bergroth E (1913) A new genus of Tipulidae from Turkestan, with notes on other forms. Annals and magazine of natural history (8)11: 575-584.

Dahl C, Alexander CP (1976) A world catalogue of Trichoceridae Kertész, 1902 (Diptera). Entomologica Scandinavica 7(1): 7-18.

Driauach O, Krzemínska E, Belqat B (2015) Genus Trichocera in Morocco: first records from Africa and a new species (Diptera: Trichoceridae). Zootaxa 4059(1): 181-190. doi: 10.11646/zootaxa.4059.1.10.

Edwards FW (1928) Diptera. Fam. Protorhyphidae, Anisopodidae, Pachyneuridae, Trichoceridae. With descriptions of early stages by D. Keilin. In: Wytsman P (Ed.) Genera insectorum. Bruxelles 90: 41.

Freeman P (1950) Trichoceridae. In: Coe RL, Freeman P, Mattingly PF (Eds) Handbooks for the identification of British Insects: Diptera, Nematocera: families Tipulidae to Chironomidae. Royal Entomological Society, London 9(2): 77-96.

Kolcsár L-P, Petrašiūnas A, Török E, Keresztes L (2018) A new species of Trichocera Meigen with further records of Metatrichocera Dahl from Bulgaria, Romania, and Serbia (Diptera, Trichoceridae). Turkish Journal of Zoology 42: 172-178. doi:10.3906/zoo1709-24.

Krzemińska E (1999) Three species with clear wings of the regelationis group: Trichocera (Metatrichocera) annulata, T. (M.) rufescens and a new species from Poland (Diptera, Trichoceridae). Acta Zoologica Cracoviensia 42(2): 251-258. 
Krzemińska E, Brunhes J (1991) Trichoceridae of Massif Central (France) (Dipt. Nematocera). Bulletin de la Société Entomologique de France 96: 49-54.

Meigen JW (1803) Versuch einer neuen Gattungs Eintheilung der europäischen zweiflügligen Insekten [An attempt to classify the European two-winged insects]. Magazin für Insektenkunde 2: 259-281. [in German]

Meigen JW (1818) Wintermükke Trichocera. Systematische Beschreibung der bekannten europäischenzweiflügeligen Insekten I (Aachen) [Winter gnats Trichocera. Systematic description of the well-known European double-winged insects] 22: 211-220. [in German]

Petrašiūnas A (2011) Short notes 20. Diptera, Trichoceridae. In: Nardi G, Whitmore D, Bardiani M, Birtele D, Mason F, Spada L, Cerretti P (Eds) Biodiversity of Marganai and Montimannu (Sardinia). Research in the framework of the ICP Forests network. Conservazione Habitat Invertebrati, 5. Cierre Edizioni, Sommacampagna, Verona, pp. 872-873.

Petrašiūnas A, Kvifte G (2016) New records of Trichoceridae (Diptera) from the island of Mallorca. Biodiversity Data Journal 4: e7610. DOI: 10.3897/BDJ.4.e7610.

Petrašiūnas A, Podenas S (2017) New data on winter crane flies (Diptera: Trichoceridae) of Korea with description of a new species. Zootaxa 4311(4): 561-575. http://dx.doi. org/10.11646/zootaxa.4311.4.8.

Petrašiūnas A, Visarcuk P (2007) Updated checklist of Lithuanian winter gnats (Diptera: Trichoceridae). Acta Zoologica Lituanica 17(4): 276-280. https://doi.org/10.1080/139 21657.2007.10512844.

Potocka M, Krzemińska E (2018) Trichocera maculipennis (Diptera) - an invasive species in Maritime Antarctica. PeerJ 6: e5408. DOI: 10.7717/peerj.5408.

Scudder SH (1894) Tertiary Tipulidae, with special reference to those of Florissant, Colorado. Proceedings of the American Philosophical Society 32: 163-245.

Starý J, Podènas S (1995) A new species of Trichocera (Metatrichocera) Meigen with further records of Metatrichocera from Switzerland (Diptera, Trichoceridae). Mitteilungen der Schweizerischen Entomologischen Gesellschaft 68: 133-136.

Thalhammer J (1900) Ordo Diptera. In: Thalhammer J (Ed.) Fauna Regni Hungariae. Animalium Hungariae hucusque cognitorum enumeratio systematica. Regia Societas Scientiarum Naturalium Hungarica. Budapest 1-76. [in Latin]

Ujvárosi L, Krzemińska E (2002) New data on Trichoceridae (Diptera) from Romania. Entomologica Romanica 7: 63-66.

Volonterio O, de León RP, Convey P, Krzemińska E (2013) First record of Trichoceridae (Diptera) in the maritime Antarctic. Polar Biology 36(8): 1125-1131. DOI 10.1007/ s00300-013-1334-4. 